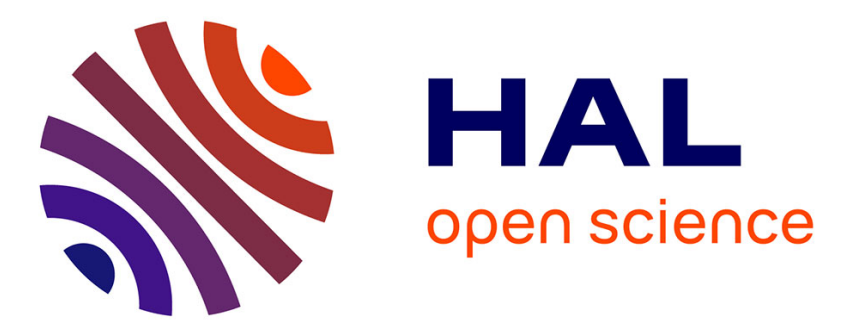

\title{
Nucleation and growth of feitknechtite from nanocrystalline vernadite precursor
}

Sylvain Grangeon, Fabienne Warmont, Christophe Tournassat, Bruno Lanson, Martine Lanson, Erik Elkaim, Francis Claret

\section{To cite this version:}

Sylvain Grangeon, Fabienne Warmont, Christophe Tournassat, Bruno Lanson, Martine Lanson, et al.. Nucleation and growth of feitknechtite from nanocrystalline vernadite precursor. European Journal of Mineralogy, 2017, 29, pp.767-776. 10.1127/ejm/2017/0029-2665 . insu-01598457

\section{HAL Id: insu-01598457 https://hal-insu.archives-ouvertes.fr/insu-01598457}

Submitted on 29 Sep 2017

HAL is a multi-disciplinary open access archive for the deposit and dissemination of scientific research documents, whether they are published or not. The documents may come from teaching and research institutions in France or abroad, or from public or private research centers.
L'archive ouverte pluridisciplinaire HAL, est destinée au dépôt et à la diffusion de documents scientifiques de niveau recherche, publiés ou non, émanant des établissements d'enseignement et de recherche français ou étrangers, des laboratoires publics ou privés. 


\title{
Nucleation and growth of feitknechtite from nanocrystalline vernadite precursor
}

\author{
SYLVAIN GRANGEON ${ }^{1, *}$, FABIENNE WARMONT $^{2}$, CHRISTOPHE TOURNASSAT $^{1,3}$, BRUNO LANSON $^{4}$, \\ MARTINE LANSON ${ }^{4}$, ERIK ELKAÏM ${ }^{5}$ and FRANCIS CLARET ${ }^{1}$ \\ ${ }^{1}$ D3E/SVP, BRGM (French Geological Survey), 3 Avenue Claude Guillemin, 45060 Orléans, France \\ *Corresponding author, e-mail: s.grangeon@brgm.fr \\ ${ }^{2}$ ICMN - CNRS - Université d'Orléans, 1b rue de la Férollerie, 45071 Orléans Cedex 2, France \\ ${ }^{3}$ UMR 7327 Institut des Sciences de la Terre d'Orléans, Université d'Orléans - CNRS/INSU - BRGM, \\ 45071 Orléans, France \\ ${ }^{4}$ Univ. Grenoble Alpes, CNRS, ISTerre, 38000 Grenoble, France \\ ${ }^{5}$ Synchrotron Soleil, L'Orme des Merisiers Saint-Aubin, BP 48, 91192 Gif-sur-Yvette Cedex, France
}

\begin{abstract}
Vernadite is a nanocrystalline manganese oxide, which controls the fate of many trace elements in soils and sediments through sorption and oxidative-degradation mechanisms. This exceptional reactivity directly results from its crystal structure, which may however evolve upon contact with redox-sensitive species. Understanding these changes is a prerequisite to predict and model the geochemical cycle of trace elements in the environment. Here, the structural and morphological modifications affecting synthetic nanocrystalline vernadite $\left(\delta-\mathrm{MnO}_{2}\right)$ upon contact with increasing concentrations of $\mathrm{Mn}^{2+}$ were investigated using wet chemistry, synchrotron X-ray diffraction and transmission electron microscopy. Fresh $\delta-\mathrm{MnO}_{2}$ crystals had an $\mathrm{Mn}$ oxidation state of $3.94 \pm 0.05$ and a $\sim 10 \AA$ layer-to-layer distance. Crystal size was $\sim 10 \mathrm{~nm}$ in the layer plane, and $\sim 1 \mathrm{~nm}$ perpendicular to that. Upon contact with aqueous $\mathrm{Mn}^{2+}$ under anoxic conditions, $\delta-\mathrm{MnO}_{2}$ crystals underwent several morphological and mineral evolutions, starting with the stacking, perpendicular to the layer plane, of $\delta-\mathrm{MnO}_{2}$ crystals to form crystals $\sim 10 \mathrm{~nm} \times 2 \mathrm{~nm}$ which were then subjected to oriented aggregation both along and perpendicular to the layer plane to form lath-like crystals with dimensions of $\sim 100 \mathrm{~nm} \times 20 \mathrm{~nm}$. Finally, these laths stacked perpendicular to the layer plane to form synthetic feitknechtite $(\beta-\mathrm{MnOOH})$ crystals with sizes up to $\sim 100 \mathrm{~nm} \times 500 \mathrm{~nm}$ when the $\mathrm{Mn}^{2+}$ loading reached $31.9 \mathrm{mmol} \mathrm{g}^{-1}$. Structural transformation from $\delta-\mathrm{MnO}_{2}$ to synthetic feitknechtite was detected at $\mathrm{Mn}^{2+}$ loading equal to or higher than $3.27 \mathrm{mmol} \mathrm{g}^{-1}$.

These mechanisms are likely to influence the geochemical fate of trace elements in natural settings where $\mathrm{Mn}^{2+}$ is abundant. Firstly, the systematic increase in crystal size with increasing $\mathrm{Mn}^{2+}$ loading may impact the sorption capacity of vernadite and feitknechtite by reducing the density of reactive edge sites. Secondly, the fate of trace elements initially sorbed at the vernadite surface is unclear, as they could either be released in solution or incorporated into the feitknechtite lattice.
\end{abstract}

Key-words: vernadite; $\delta-\mathrm{MnO}_{2}$; feitknechtite; $\beta-\mathrm{MnOOH} ;$ manganese oxide; X-ray diffraction; transmission electron microscopy; nucleation; sorption; crystal growth.

\section{Introduction}

Manganese (Mn) oxides are ubiquitous in surficial environments, where they play a key role in the geochemical cycles of major and trace elements, as they are highly reactive towards nutrients (e.g., Xin et al., 2016), metals (e.g., Halbach, 1986; Bellanca et al., 1996; Manceau et al., 2004, 2007, 2014; Marcus et al., 2004; Boonfueng et al., 2006; Fuller \& Bargar, 2014), actinides (e.g., Kunzendorf \& Friedrich, 1976; Koppi et al., 1996; Duff et al., 1999) and organic matter and organic molecules (e.g., Cheney et al., 1996; Nasser et al., 2000; Barrett \& McBride, 2005; Chang Chien et al., 2009; Johnson et al., 2015). Vernadite, the nanocrystalline and turbostratic analogue to birnessite (Giovanoli, 1980), is one of most abundant (Taylor et al., 1964; Taylor, 1968; Ross et al., 1976; Birnie \& Paterson, 1991) and reactive Mn oxides, especially in suboxic aqueous systems such as the upper soil. The vernadite structure consists in the turbostratic stacking of layers of $\left(\mathrm{Mn}^{4+} \mathrm{O}_{6}\right)^{8-}$ octahedra connected through their edges and separated from each other by hydrated interlayer cations (e.g., Giovanoli, 1980; Chukhrov et al., 1985; Jurgensen et al., 2004; Villalobos et al., 2006; Grangeon et al., 2008). In natural settings, vernadite mainly has hexagonal layer symmetry (e.g., Marcus et al., 2004; Manceau et al., 2007, 2014; Bargar et al., 2009). These layers may contain vacancies and/or isomorphic substitutions of $\mathrm{Mn}^{4+}$ by cations of lower 
valence (e.g., $\mathrm{Mn}^{3+}, \mathrm{Ni}^{2+}, \mathrm{Co}^{3+}$; Manceau et al., 1997, 2014; Peacock \& Sherman, 2007; Lanson et al., 2008; Peña et al., 2010; Grangeon et al., 2014) which, together with the minute size of the layers $(5-10 \mathrm{~nm}$, e.g., Hochella et al., 2005; Bargar et al., 2009), are responsible for the exceptional reactivity of vernadite. The possible contact with redox-sensitive species such as $\mathrm{Mn}^{2+}$ can induce structural changes whose nature and extent depend on solution $\mathrm{pH}$ and $\mathrm{Mn}^{2+}$ concentration. The first step of reaction between aqueous $\mathrm{Mn}^{2+}$ and layer $\mathrm{Mn}^{4+}$, hereafter referred to as $\mathrm{Mn}^{2+}{ }_{(\text {aq) }}$ and $\mathrm{Mn}^{4+}{ }_{(\mathrm{s})}$, respectively, is (Elzinga, 2016):

$\mathrm{Mn}_{(\mathrm{aq})}^{2+}+\mathrm{Mn}_{(\mathrm{s})}^{4+} \rightarrow 2 \mathrm{Mn}^{3+}{ }_{(\mathrm{s})}$,

where $\mathrm{Mn}^{3+}$ (s) is layer $\mathrm{Mn}^{3+}$. The $2 \mathrm{Mn}^{3+}$ (s) formed may further disproportionate, returning the system to its initial state. Alternatively, they may accumulate in the structure and induce a change in layer symmetry, from hexagonal to orthogonal, as observed experimentally at $\mathrm{pH} 9$ when the molar ratio of $\mathrm{Mn}^{2+}$ to $\delta-\mathrm{MnO}_{2}$ is lower than 0.05 (Zhao et al., 2016). At lower $\mathrm{pH}$ and/or at higher $\mathrm{Mn}^{2+}$ concentration, a transformation to synthetic feitknechtite $(\beta-\mathrm{MnOOH})$ is observed, following the reaction:

$$
\delta-\mathrm{Mn}^{4+} \mathrm{O}_{2}+\mathrm{Mn}^{2+}{ }_{(\mathrm{aq})} \rightarrow 2 \beta-\mathrm{Mn}^{3+} \mathrm{OOH} \text {. }
$$

Feitknechtite, whose structure is built of layers of $\left(\mathrm{Mn}^{3+} \mathrm{O}_{6}\right)^{9-}$ octahedra, may upon ageing convert to manganite $(\gamma-\mathrm{MnOOH})$ at $\mathrm{pH} 7.0-7.5$ or to hausmannite $\left(\mathrm{Mn}_{3} \mathrm{O}_{4}\right)$ at $\mathrm{pH}>8$ (Elzinga, 2011; Lefkowitz et al., 2013; Lefkowitz \& Elzinga, 2015).

The interplay between these structural transformations certainly influences the geochemical cycle of trace elements by modifying the reactivity of $\mathrm{Mn}$ oxides through a change in the nature and density of local crystal charges, but also by modifying the fate of trace elements initially adsorbed at the vernadite surface which, by analogy with the phyllomanganate-to-tectomanganate transformation, could either be incorporated in the structure during transformation or released to solution (Atkins et al., 2014, 2016; Grangeon et al., 2015).

The present study aimed at contributing to a better understanding of the vernadite-to-feitknechtite transformation, and in particular at elucidating the reaction mechanisms at the crystal scale, using wet chemistry, X-ray diffraction (XRD) and transmission electron microscopy (TEM).

\section{Materials and methods}

\subsection{Sample synthesis, sorption experiments and chemical analyses}

The $\delta-\mathrm{MnO}_{2}$ phase was synthesized using a redox method described elsewhere (Villalobos et al., 2003). The average oxidation state (AOS) of Mn was determined by using a potentiometric method (Grangeon et al., 2012). After synthesis, samples were Na-saturated through ten cycles of centrifugation, supernatant removal and resuspension in a
$1 \mathrm{M} \mathrm{NaCl}$ solution. A last step of three similar cycles with de-ionized water instead of $1 \mathrm{M} \mathrm{NaCl}$ was then performed. The obtained $\delta-\mathrm{MnO}_{2}$ paste was immediately freeze-dried, and the resulting powder was introduced in a $\mathrm{N}_{2}$-filled glove box where it was left for $\sim 7 \mathrm{~d}$. Eight aliquots of $\sim 20-40 \mathrm{mg}$ powder each were then introduced in previously weighted dialysis membranes. Filled membranes were weighted, filled with a solution containing $0.1 \mathrm{M} \mathrm{NaCl}$ and $\mathrm{MnCl}_{2}$ at a concentration ranging 0 $0.04 \mathrm{M}$, sealed, and introduced in $50 \mathrm{~mL}$ polypropylene tubes, to which $40.5-45 \mathrm{~mL}$ of the solution introduced in the dialysis membrane were added. Initial solution $\mathrm{pH}$ was 6.5. Tubes were sealed and left to agitate for $24 \mathrm{~h}$. The dialysis membrane was then separated from the solution whose final $\mathrm{pH}$ ranged between 6.5 and 5.8. The solution was acidified to $\mathrm{pH} \sim 3$ with $\mathrm{HNO}_{3}$ and analyzed for its $\mathrm{Mn}^{2+}$ content using an ICP-AES (Horiba-Jobin Yvon Ultima 2). The magnitude of $\mathrm{Mn}^{2+}$ retention by $\delta-\mathrm{MnO}_{2}$ was quantified using the $R_{\mathrm{D}}$ factor (Tournassat et al., 2013) defined as:

$R_{\mathrm{D}}=\frac{C_{\text {init }}-C_{\mathrm{aqu}}}{C_{\mathrm{aqu}} \times R_{\mathrm{SL}}}$,

where $C_{\text {init }}$ is the initial concentration of $\mathrm{Mn}^{2+}, C_{\text {aqu }}$ the $\mathrm{Mn}^{2+}$ concentration in solution after equilibration, and $R_{\mathrm{SL}}$ is the solid-to-liquid ratio in the experiment (in $\mathrm{kg} \mathrm{L}^{-1}$ ).

The dialysis membrane was opened and the solid separated by filtration $(0.01 \mu \mathrm{m}$ cut-off $)$ before being washed with bi-distilled water. An aliquot was freezedried for TEM analysis, whereas the remaining was sealed in a polyimide capillary for XRD analysis in the wet state within $48 \mathrm{~h}$. Samples were labelled MndBi-XX, where XX is the $\mathrm{Mn}^{2+}$ loading (in $\mathrm{mmol} \mathrm{Mn}{ }^{2+}$ per g of dry $\delta-\mathrm{MnO}_{2}$ ).

\subsection{Synchrotron X-ray diffraction}

The XRD experiments were carried out at station CRISTAL (SOLEIL synchrotron in Orsay, France), using an energy of $28.44 \mathrm{keV}(\lambda=0.436 \AA)$ and an XPad hybrid pixel detector. Data were recorded over the $1.2-124.5^{\circ} 2 \theta$ range with a total collection time of $30 \mathrm{~min}$ and processed with a specific software (Ounsy et al., 2013). To ease comparison with previous studies (e.g., Grangeon et al., $2015,2017)$, diffraction data will be expressed relative to the scattering vector $q$, where $q=[4 \times \pi \times \sin (\theta)] / \lambda$.

\subsection{Transmission electron microscopy}

The TEM experiments were carried out using a Philips CM20 microscope operated at $200 \mathrm{kV}$. Prior to observation, samples were embedded in epoxy resin, left to polymerize for $48 \mathrm{~h}$ in the dark and cut with an ultramicrotome (Reichert-Jung Ultra-cut E) equipped with a diamond knife. The $\sim 80 \mathrm{~nm}$ thick sections were picked up on lacey carbon films loaded on $\mathrm{Cu}$ grids. In addition, to assess possible preparation-induced artefacts (use of an ultramicrotome), a sample identical to MndBi-0.5 (Table 1) was prepared according to the above described protocol, filtered and 
Table 1. Experimental conditions of $\delta-\mathrm{MnO}_{2}$ contacts with $\mathrm{Mn}^{2+}{ }_{\text {(aq) }}$ and chemical characterization of reacted solids.

\begin{tabular}{llcccc}
\hline Sample & Mn AOS & $\mathrm{Mn}_{\text {sorbed }}^{2+}\left(\mathrm{mmol} \mathrm{g}^{-1}\right)$ & $C_{\mathrm{aqu}}\left(\mathrm{mmol} \mathrm{L}^{-1}\right)$ & $R_{\mathrm{SL}}\left(\mathrm{gL}^{-1}\right)$ & $\log \left(R_{\mathrm{D}}\right)\left(R_{\mathrm{D}}\right.$ in L kg \\
\hline MndBi-0 & $3.94 \pm 0.05$ & n.d. & n.d. & 0.65 & .d. \\
MndBi-0.5 & $3.80 \pm 0.05$ & 0.49 & 0.03 & 0.70 & 4.21 \\
MndBi-1.5 & n.d. & 1.49 & 0.41 & 0.68 & 3.56 \\
MndBi-3.3 & $3.54 \pm 0.10$ & 3.27 & 0.94 & 0.73 & 3.54 \\
MndBi-8.6 & n.d. & 8.61 & 2.41 & 0.49 & 3.55 \\
MndBi-11.3 & n.d. & 11.32 & 12.15 & 0.91 & 3.25 \\
MndBi-28.1 & $3.62^{\mathrm{a}}$ & 28.05 & 20.47 & 0.64 & 3.36 \\
MndBi-31.9 & n.d. & 31.90 & 0.55 & 3.19 \\
\hline
\end{tabular}

Notes: $\mathrm{Mn}^{2+}$ loading at the end of the experiment $\left(\mathrm{Mn}^{2+}\right.$ sorbed $)$ is the number of mmol of $\mathrm{Mn}^{2+}$ sorbed per g of $\delta$ - $\mathrm{MnO}{ }_{2}$. n.d. stands for "not determined".

${ }^{\text {a }}$ May be subject to high uncertainties as a single measurement was performed.

re-suspended in alcohol. A drop of the obtained suspension was deposited on a $\mathrm{Cu}$ grid. Fast-Fourier transform (FFT) analysis of the micrographs was done with ImageJ (Schneider et al., 2012).

\section{Results and discussion}

\subsection{Determination of $\mathrm{Mn}^{2+}$ retention coefficient}

An increase in $\mathrm{Mn}^{2+}{ }_{\text {(aq) }}$ resulted in a decrease in the $\mathrm{Mn}$ AOS of the final solids, suggesting retention of $\mathrm{Mn}^{2+}$ on $\delta-\mathrm{MnO}_{2}$ (Table 1). The $R_{\mathrm{D}}$ values (Table 1) compared well with previously reported values obtained after $8 \mathrm{~d}$ of equilibration (Fig. 1). The evolution of $R_{\mathrm{D}}$ as a function of $\mathrm{Mn}^{2+}$ concentration and $\mathrm{pH}$ (Murray, 1975) has, in some cases, been interpreted in terms of adsorption and quantified in surface-complexation models (Appelo \& Postma, 1999; Tonkin et al., 2004). Data interpreted with these models had a $\mathrm{Mn}^{2+}$ loading ranging from 1 to 12 $\mathrm{Mn}^{2+}$ per $\mathrm{nm}^{2}$, depending on the dataset and on the specific surface area considered (value measured by the authors or $600 \mathrm{~m}^{2} \mathrm{~g}^{-1}$ as recommended by Tonkin et al., 2004). Such loading roughly corresponds to MndBi-1.5 $\left(1.5 \mathrm{Mn}^{2+}\right.$ per $\mathrm{nm}^{2}$ assuming a specific surface area of $600 \mathrm{~m}^{2} \mathrm{~g}^{-1}$ ), which means that this sample and MndBi-0.5 could have been interpreted in the frame of these models. For other samples, the density of $\mathrm{Mn}^{2+}$ at the surface of $\delta-\mathrm{MnO}_{2}$ would be unrealistically high (up to $32 \mathrm{Mn}^{2+}$ per $\mathrm{nm}^{2}$ for MndBi-31.9), and interaction of $\mathrm{Mn}^{2+}$ with $\delta-\mathrm{MnO}_{2}$ most likely resulted in a structure transformation, which was studied by XRD.

\subsection{Mineralogical evolution}

Two sets of reflections could be observed in the XRD pattern of MndBi-0 (Fig. 2), which was not in contact with $\mathrm{Mn}^{2+}$, both being consistent with a nanocrystalline turbostratic phyllomanganate structure. The first set corresponded to broad and asymmetric reflections at $2.58 \AA^{-1}, 4.42 \AA^{-1}$ and $5.11 \AA^{-1}(d$-spacing of $2.44 \AA$, $1.42 \AA$ and $1.23 \AA$ ). The reflection at $4.42 \AA^{-1}$ was shown to be indicative of layer symmetry: approximately symmetric when layer symmetry is hexagonal, but split in two distinct maxima when layer symmetry is orthogonal

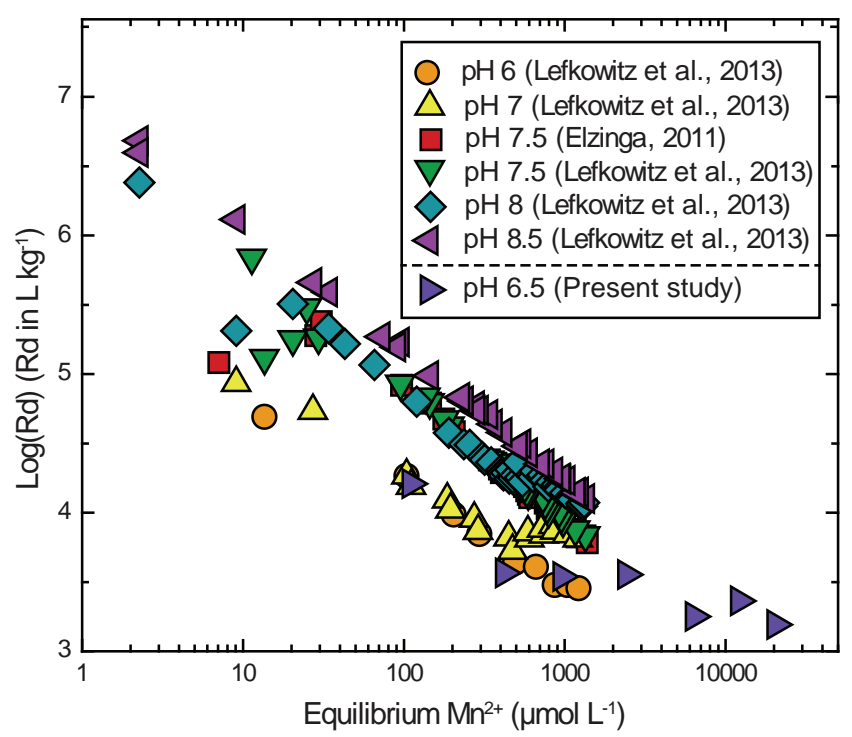

Fig. 1. Evolution of the $\mathrm{Mn}^{2+}$ retention coefficient as a function of $\mathrm{Mn}^{2+}$ concentration. Patterns are indicative of the experiment $\mathrm{pH}$ : circles and triangles pointing up, experiments conducted at $\mathrm{pH} 6$ and $\mathrm{pH} 7$, respectively; squares and triangles pointing down, $\mathrm{pH} 7.5$; diamonds, $\mathrm{pH} 8$; triangles pointing left, $\mathrm{pH} 8.5$ (Elzinga, 2011; Lefkowitz et al., 2013). Published data were collected with a contact time of 8 d. Present data ( $\mathrm{pH} 6.5 ; 1$ d contact time) are shown as triangles pointing right.

(Drits et al., 2007). Here, it was symmetric despite the presence of a shoulder on the low- $q$ side, related to a basal reflection (see below), and layer symmetry was hexagonal. For consistency with previous studies (e.g., Lanson et al., 2000, 2008; Webb et al., 2005; Drits et al., 2007; Grangeon et al., 2010, 2012; Zhu et al., 2010; Manceau et al., 2013), bands were indexed with an orthogonal symmetry system $\left(a=\sqrt{ } 3 \times b, \gamma=90^{\circ}\right)$ and the three maxima were indexed as $(11,20),(31,02)$ and $(22,40)$ $h k$ band, respectively. Reflections of the second set were sharp and symmetric and formed a rational series of $00 l$ reflections at $0.62 \AA^{-1}, 1.24 \AA^{-1}$ and $1.85 \AA^{-1}(10.15 \AA$, $5.08 \AA$ and $3.39 \AA$ ). The layer-to-layer distance, inferred from the position of the 003 at $1.85 \AA^{-1}$, was $10.17 \AA$. When increasing $\mathrm{Mn}^{2+}$ loading up to $1.5 \mathrm{mmol} \mathrm{g}^{-1}$ (MndBi-1.5), the intensity of the $00 l$ reflections decreased, but the position remained essentially unchanged and 


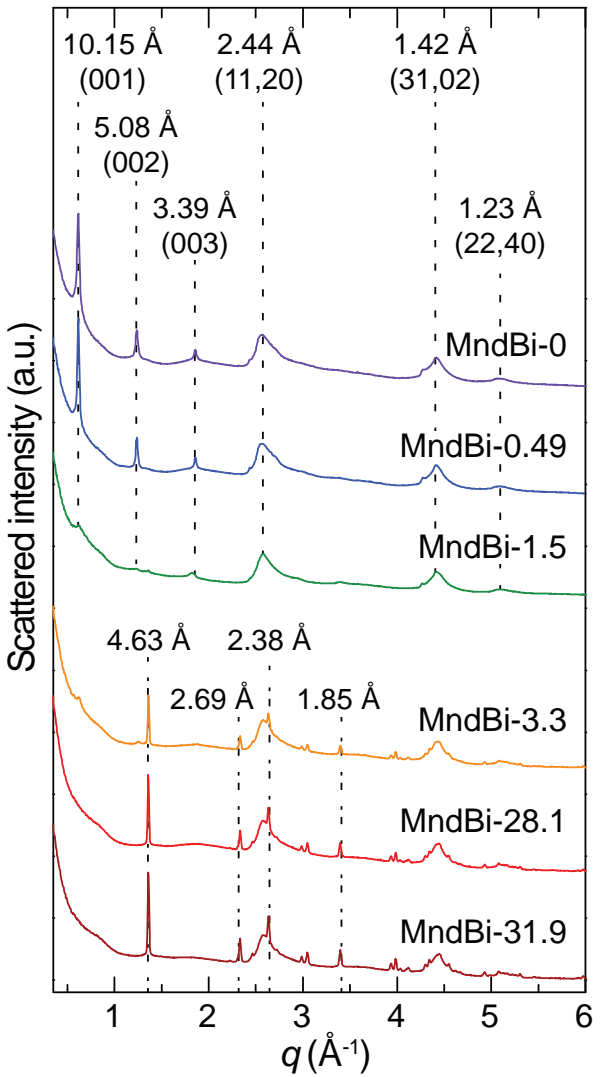

Fig. 2. From top to bottom, XRD patterns of MndBi-0, MndBi-0.5, MndBi-1.5, MndBi-3.3, MndBi 28.1 and MndBi-31.9. Dashed lines and dashed-dotted lines point out to the presence of diffraction maxima of $\delta-\mathrm{MnO}_{2}$ and synthetic feitknechtite, respectively.

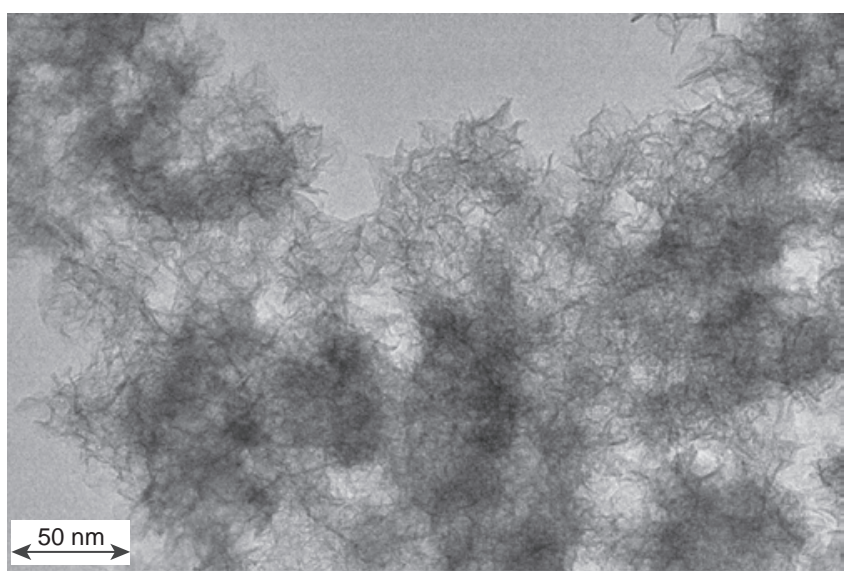

Fig. 3. Transmission electron microscope (TEM) observation of type 1 crystals from MndBi-0.

$h k$ bands were unaffected. The shoulder on the low- $q$ side of the $(31,02)$ band weakened, supporting its indexation as the 006 reflection. Note the presence of a weak peak at $\sim 1.36 \AA^{-1}(\sim 4.6 \AA)$ in the XRD pattern of MndBi-1.5, which could be attributed to synthetic feitknechtite (see below). Weakening of $00 \mathrm{l}$ reflections can be interpreted as a loss of parallelism between adjacent layers and was attributed to the incorporation of $\mathrm{Mn}^{3+}$ (s) according to the comproportionation mechanism described above. Indeed, $\mathrm{Mn}^{3+}$ octahedra are distorted by the Jahn-Teller effect and their presence within the octahedral layer induces strains that ultimately lead to layer kinking (Webb et al., 2005; Atkins et al., 2014; Grangeon et al., 2014) and subsequent loss of parallelism between layers. In addition to $h k$ bands of $\delta-\mathrm{MnO}_{2}$, the XRD pattern of MndBi-3.3 $\left(3.3 \mathrm{Mn}^{2+}\right.$ per $\mathrm{nm}^{2}$ ) had additional reflections, e.g., at $1.36 \AA^{-1}, 2.34 \AA^{-1}$, $2.64 \AA^{-1}$ and $3.40 \AA^{-1}(4.63 \AA, 2.69 \AA, 2.38 \AA$, and $1.85 \AA)$, assigned to synthetic feitknechtite (Bricker, 1965). As the latter reflections became more intense with increasing $\mathrm{Mn}^{2+}$ loading, up to $31.90 \mathrm{mmol} \mathrm{g}^{-1}$ (MndBi-31.9), the proportion of synthetic feitknechtite increased with $\mathrm{Mn}^{2+}$ loading.

Such an evolution was consistent with previous studies (Elzinga, 2011, 2016; Lefkowitz et al., 2013; Lefkowitz \& Elzinga, 2015). In the following section, the mechanisms of transformation were studied at the crystal scale, hypothesizing that an increased concentration of $\mathrm{Mn}^{2+}$ led to an increased conversion of $\delta-\mathrm{MnO}_{2}$ to synthetic feitknechtite without significant dissolution of $\delta-\mathrm{MnO}_{2}$. In other words, it was hypothesized that the structural and morphological evolution of samples following their contact with a given concentration of $\mathrm{Mn}^{2+}{ }_{\text {(aq) }}$ underwent intermediate recrystallization steps similar to those observed during post-mortem analysis of samples in contact with lower concentrations of $\mathrm{Mn}^{2+}{ }_{(\mathrm{aq})}$. This hypothesis is supported by previous TEM observations, from which it was concluded that there was a lack of significant dissolution/reprecipitation during the recrystallization of $\delta-\mathrm{MnO}_{2}$ when in contact with aqueous $\mathrm{MnSO}_{4}$ (Tu et al., 1994). Absence of $\delta-\mathrm{MnO}_{2}$ dissolution is further substantiated by the study of Elzinga \& Kustka (2015) showing that the first steps of transformation involves solely comproportionation and disproportionation reactions induced by interfacial electron transfer between adsorbed $\mathrm{Mn}^{2+}$ and $\mathrm{Mn}^{4+}$ (s). Experimental validation of this hypothesis would require performing a kinetic experiment at high $\mathrm{Mn}^{2+}{ }_{(\mathrm{aq})}$ concentration to check whether recrystallization steps observed as a function of $\mathrm{Mn}^{2+}$ concentration are similar to those occurring as a function of time. Such a procedure was applied to the study of the $\delta-\mathrm{MnO}_{2}$ to synthetic todorokite transformation (Atkins et al., 2014, 2016), but was not possible in the present case because of reaction kinetics. The $R_{\mathrm{D}}$ values obtained in the present study after $1 \mathrm{~d}$ of contact time were identical to those reported previously for a contact time of $8 \mathrm{~d}$ (Fig. 1). Steady-state was thus reached in less than $1 \mathrm{~d}$ of contact time, consistent with previous observations showing that feitknechtite is formed in less than $20 \mathrm{~min}$ (Johnson et al., 2016) and that sorption of $\mathrm{Mn}^{2+}$ at the $\delta-\mathrm{MnO}_{2}$ surface is completed within less than $1 \mathrm{~s}$ (Fendorf et al., 1993).

\subsection{Morphological evolution during $\delta-\mathrm{MnO}_{2}$ to synthetic feitknechtite transformation}

Sample MndBi- 0 consisted of crystals $\sim 10 \mathrm{~nm}$ in their largest dimension (presumably the layer plane) and $\sim 1 \mathrm{~nm}$ perpendicular (Fig. 3), henceforth denominated 

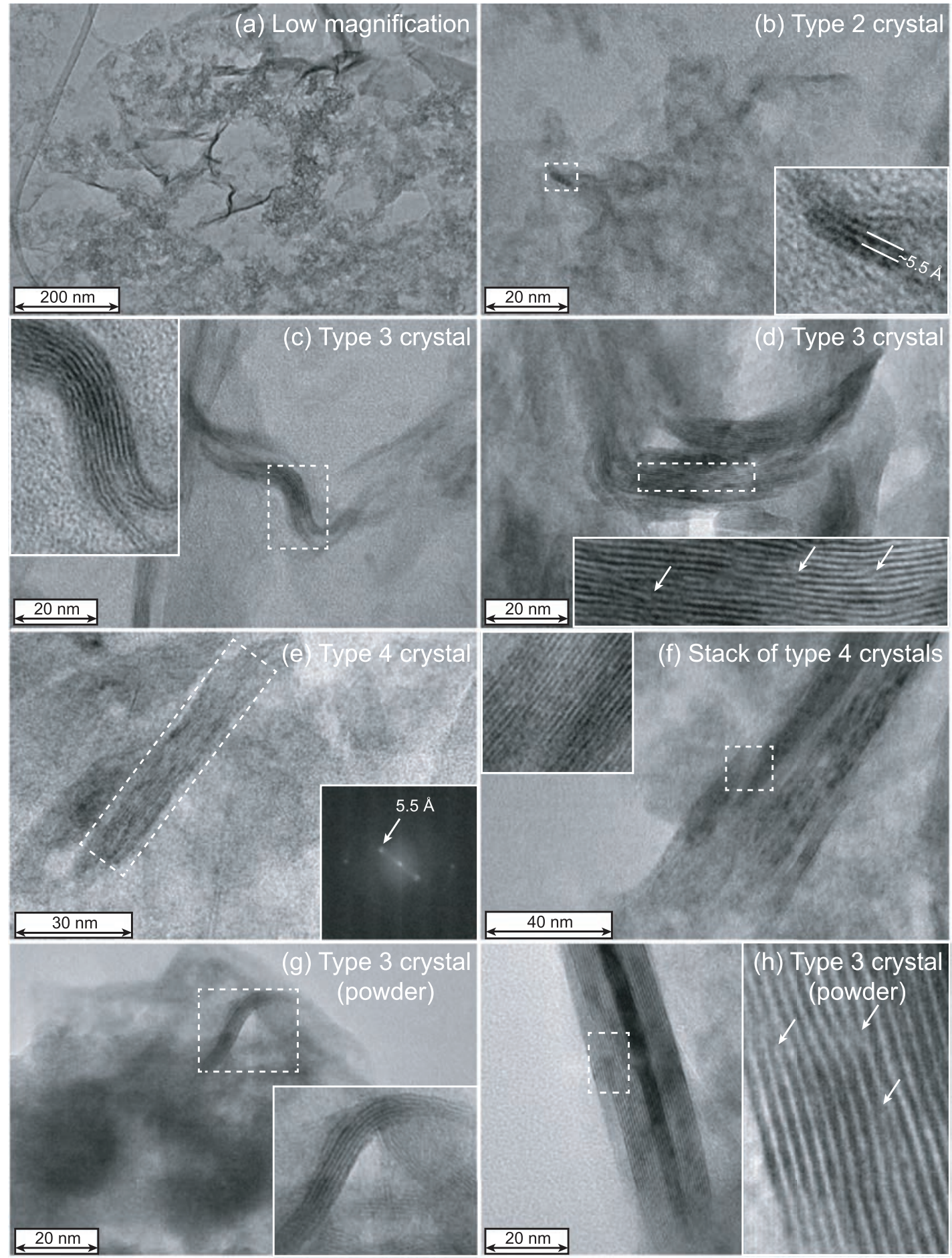

Fig. 4. TEM observation of MndBi-0.5. (a) Low-magnification view; (b) type-2 crystal; (c) and (d) type-3 crystals; (e) type-4 crystal; (f) crystal built from the stacking of type- 4 crystals; $(\mathrm{g})$ and $(\mathrm{h})$ type- 3 crystals deposited on the $\mathrm{Cu}$ grid from a drop of suspension instead of microtome preparation. Insets in (b), (c), (d), (f), (g) and (h) are enlarged views of regions delimited with dotted squares. In (d) and (h), arrows point to the presence of dislocations. The inset in (e) is a fast-Fourier transform (FFT) analysis of the region shown with a dotted square.

type- 1 crystals. The crystal size in the layer plane was in good qualitative agreement with the XRD data, in which broad $h k$ bands could be observed, indicative of crystallites $\sim 5-10 \mathrm{~nm}$ in the layer plane (Lanson et al., 2008; Grangeon et al., 2012; Manceau et al., 2013). On the other hand, the small crystal size perpendicular to the layer plane contrasted with the sharp $00 \mathrm{l}$ reflections. This apparent contradiction could be concealed assuming that TEM sample preparation procedure has delaminated $\delta-\mathrm{MnO}_{2}$ crystals. 

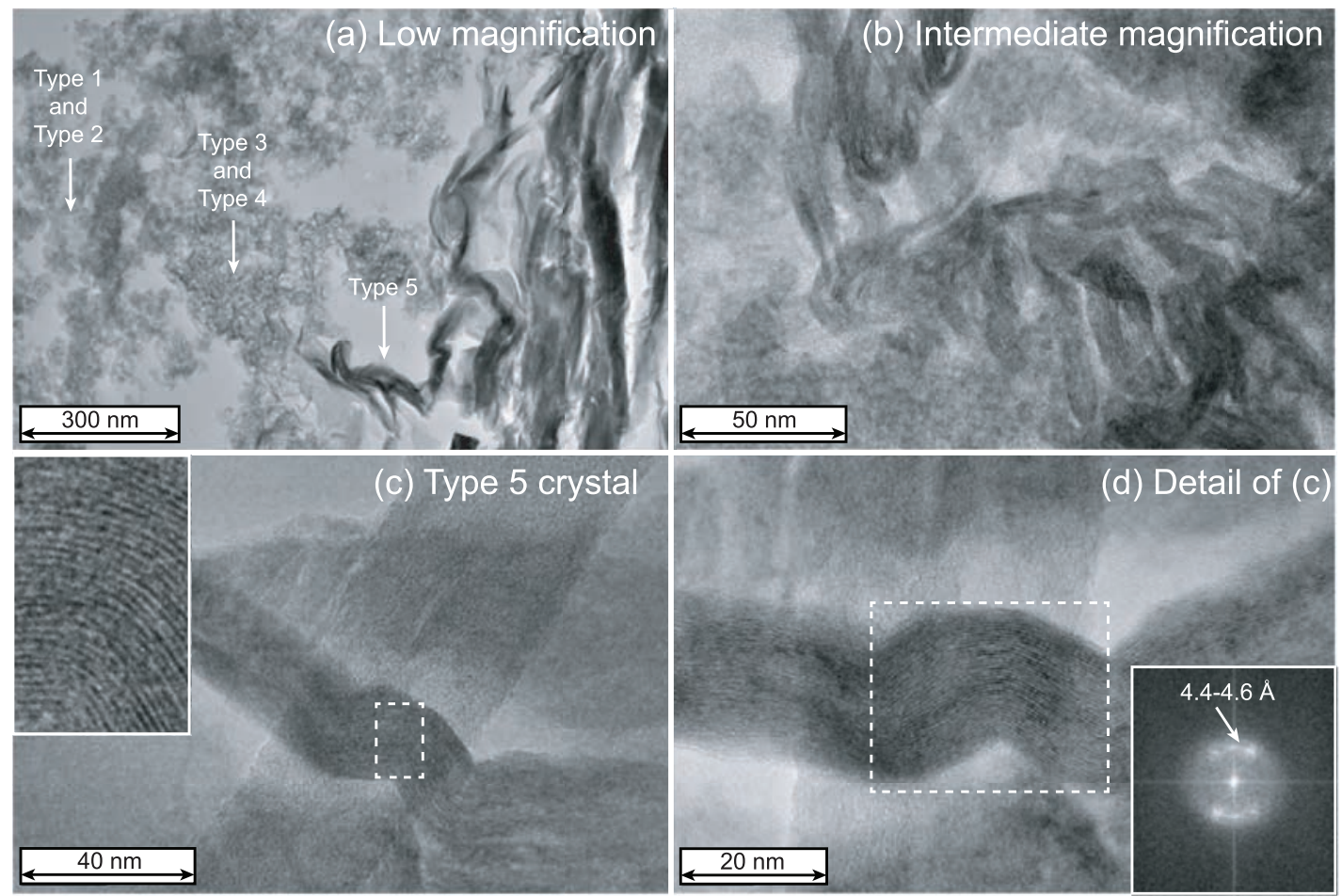

Fig. 5. TEM observation of MndBi-1.5. (a) Low-magnification view with the different crystal morphologies indicated with arrows; (b) type-5 crystals at intermediate magnification; (c) type-5 crystal exhibiting layer bending. The area shown with a dotted square in (c) is enlarged in the inset. (d) A detailed view of (c) and the inset is a FFT analysis of the region shown with a dotted square.

Observation of MndBi- 0.5 evinced that a $\mathrm{Mn}^{2+}$ loading as low at $0.49 \mathrm{mmol} \mathrm{g}^{-1}$ led to the formation of crystals with contrasting morphologies and sizes, ranging $\sim 10$ $200 \mathrm{~nm}$ in the layer plane (Fig. 4a). In addition to type-1 crystals, three types of such crystals were identified:

- Type- 2 crystals had a size of $\sim 10 \mathrm{~nm}$ in the layer plane, $\sim 2-3 \mathrm{~nm}$ perpendicular, and were bent (Fig. 4b), probably as a result of the incorporation of $\mathrm{Mn}^{3+}{ }_{(\mathrm{s})}$ in layers containing mainly $\mathrm{Mn}^{4+}$. The layer-to-layer distance was $\sim 5.5 \AA$, typical for dehydrated phyllomanganates (Cygan et al., 2012; Wegorzewski et al., 2015). Dehydration was possibly induced by sample freezedrying or by the secondary vacuum in the TEM. For type- 1 and type- 2 crystals having similar lateral dimensions, it is proposed that the latter formed from the coherent stacking of the former;

- Type- 3 crystals were $\sim 50 \mathrm{~nm}$ in the layer plane, and were built of $\sim 10-20$ layers stacked parallel to each other, with a layer-to-layer distance of $\sim 5.5 \AA$ (Fig. $4 \mathrm{c}, \mathrm{d}$ ). As type-2 crystals, they were bent. Images of the lateral terminations of type- 3 crystals showed that they consisted of stacked type-2 crystals (Fig. 4c). Layer dislocations were observed also on some crystals (Fig. 4d), suggesting that type- 2 crystals connected also within the layer plane to form type3 crystals. Most likely, the type- 3 crystals thus originated from the oriented aggregation of type- 2 crystals, both within the layer plane and perpendicular to it;

- Type 4 crystals had lath-like shape, dimensions of $\sim 50-100 \mathrm{~nm}$ in the layer plane and $\sim 10-20 \mathrm{~nm}$ perpendicular (Fig. 4e), layer-to-layer distance of
$5.5 \AA$ (inset in Fig. 4e), and were rarely found as stacks (Fig. 4f). It is speculated that they resulted from the same aggregation mechanisms proposed for the type-3 crystals, but with fewer defects between connected type- 2 crystals and/or a specific distribution of $\mathrm{Mn}^{3+}$ (s) so as to minimize layer strains and bending. Note that layer bending and dislocations observed in type-3 crystals cannot be related to sample preparation, as crystals deposited from a drop of a $\delta-\mathrm{MnO}_{2}$ suspension exhibited similar microstructural features (Fig. 4g, h).

These observations demonstrate that the surface of $\delta-\mathrm{MnO}_{2}$ is modified at loadings as low as $0.5 \mathrm{Mn}^{2+}$ per $\mathrm{nm}^{2}$. As a consequence, surface complexation models, which rely on a reversible sorption hypothesis (Tournassat et al., 2013), may not be suited to describe $\mathrm{Mn}^{2+}$ interaction with $\delta-\mathrm{MnO}_{2}$.

All types of crystals found in samples with lower $\mathrm{Mn}^{2+}$ loadings were observed in MndBi-1.5 that contained also larger crystals (type-5), $100-150 \mathrm{~nm}$ in the layer plane and $\sim 20-30 \mathrm{~nm}$ perpendicular (Fig. 5a). In contrast, XRD indicated that MndBi-1.5 consisted mainly of isolated $\delta-\mathrm{MnO}_{2}$ nanosheets. However, type- 5 crystals were bent (Fig. 5b). Bending did not involve layer disruption (Fig. $5 \mathrm{c}$ ), but likely led to variable layer-to-layer distance, best quantified from FFT analysis of the images (Fig. 5d). This analysis showed that layer-to-layer distance varied within a given crystal, being equal to 4.4-4.6. . Both layer bending and layer-to-layer distance heterogeneity within a given crystal reduced crystallite size within the layer plane and led to vanishing of $00 l$ reflection. 
Finally, MndBi-28.1 contained, in addition to all previously mentioned types of crystals, type- 6 crystals (Fig. 6) whose selected-area electron diffraction (SAED) patterns were typical for synthetic feitknechtite (Fig. 6c). These crystals were up to $\sim 100 \mathrm{~nm} \times 500 \mathrm{~nm}$ and were built of the stacking of laths resembling type- 5 crystals but free of stacking defects and dislocations. These laths were not simply aligned, but were connected (Fig. 6d, e), as shown by both the observation of interference fringes (inset in Fig. 6e) and the FFT image analysis showing a homogeneous layer-to-layer distance (4.4 $\mathrm{A}$, inset in Fig. 6e). It is proposed that type- 6 crystals formed from the oriented aggregation, perpendicular to the layer plane, of type-5 crystals. The presence of dislocations in type- 5 crystals is thought to have inhibited their oriented aggregation. Bending was not observed either in type- 6 crystals, possibly because all $\mathrm{Mn}^{4+}{ }_{(\mathrm{s})}$ was converted to $\mathrm{Mn}^{3+}{ }_{(\mathrm{s})}$, allowing for their specific distribution to accommodate their Jahn-Teller distortion. No $\mathrm{Mn}^{2+}$-rich phase could be detected with SAED, despite a molar ratio of sorbed $\mathrm{Mn}^{2+}$ to structural $\delta-\mathrm{MnO}_{2} \mathrm{Mn}$ of 3 (assuming a defect-free $\delta-\mathrm{MnO}_{2}$ and a molar mass of $119 \mathrm{~g} \mathrm{~mol}^{-1}$, Giovanoli et al., 1970). Consequently, it was concluded that part of the $\mathrm{Mn}^{2+}$ was sorbed by $\delta-\mathrm{MnO}_{2}$ and/ or synthetic feitknechtite, or precipitated as an amorphous phase.

\subsection{The role of oriented aggregation in nanoparticle growth}

The present description of the vernadite-to-feitknechtite transformation, from macroscopic to crystal scales, is consistent with our current understanding of this transformation (Elzinga, 2011, 2016; Lefkowitz et al., 2013; Lefkowitz \& Elzinga, 2015). One of the key findings is the major role of oriented aggregation in the nucleation and growth of feitknechtite from $\delta-\mathrm{MnO}_{2}$ precursors. This process is increasingly recognized as one of the main processes responsible for nanoparticle growth (Penn, 2004; Niederberger \& Colfen, 2006; Yuwono et al., 2010): carbonates (Shen et al., 2006), iron (Jia \& Gao, 2008a and b) and manganese (Portehault et al., 2007 ) oxides. It was also shown to be responsible for the phase transformations of nanoparticle precursors (e.g., Hockridge et al., 2009). Recently, oriented aggregation was shown to be involved in the formation of synthetic todorokite and cryptomelane from a $\delta-\mathrm{MnO}_{2}$ precursor (Chen et al., 1986; Atkins et al., 2014, 2016; Grangeon et al., 2015) and in the change of $\delta-\mathrm{MnO}_{2}$ layer symmetry, from hexagonal to orthogonal (Zhao et al., 2016). It is thus possible to speculate that Mn oxides found in surficial environments were to a large extent formed from vernadite precursors (Bodeï et al., 2007; Xu et al., 2010), possibly through oriented aggregation mechanisms.
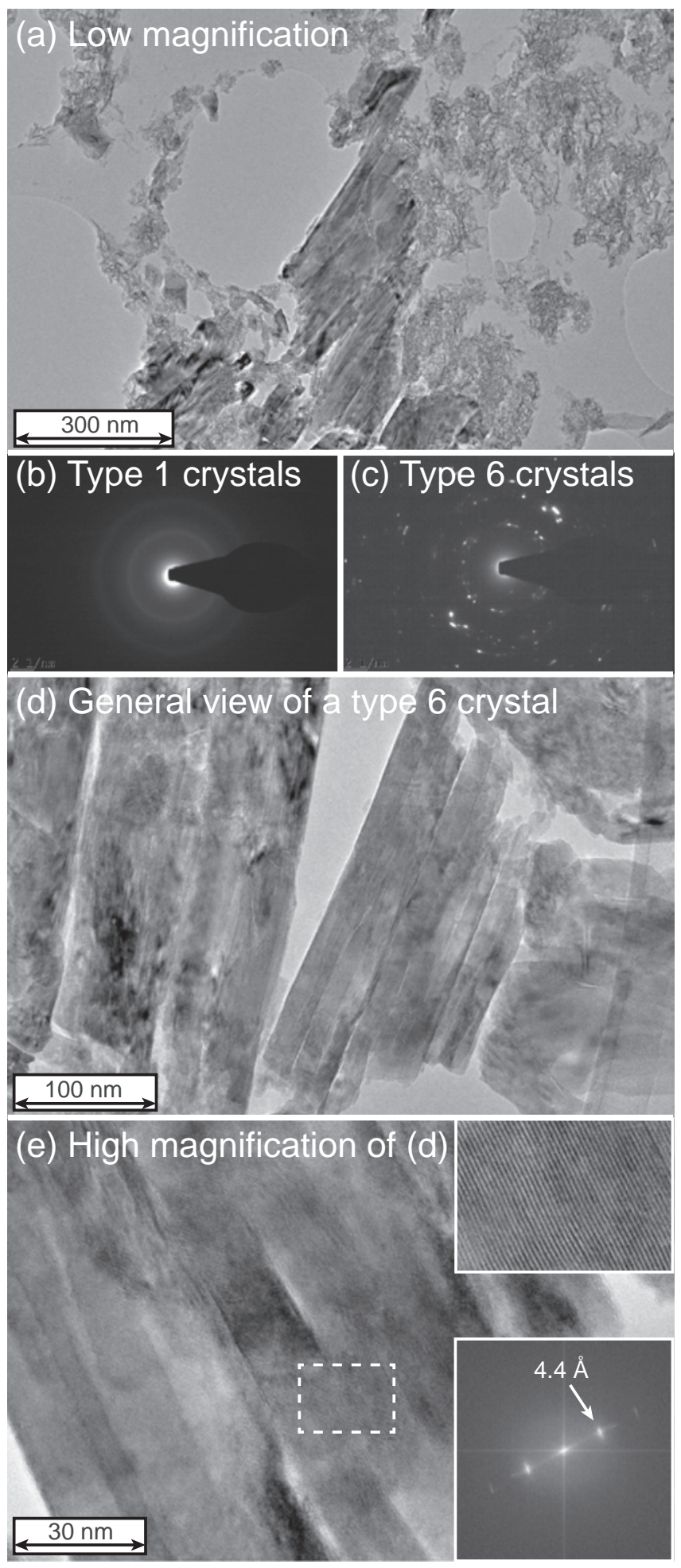

Fig. 6. TEM observation of MndBi-28.1. (a) Low-magnification view; (b) and (c) SAED patterns collected on the smallest crystals (top right in (a)) and the biggest crystals (centre in (a)), respectively; (d) and (e) type- 6 crystal. The FFT analysis shown as an inset at the bottom right of (e) was calculated over the whole image while the inset at the top right is an enlarged view of the area delimited with a dotted square. 


\section{Concluding remarks: environmental implications}

Vernadite with hexagonal layer symmetry is a sink for many trace elements in the environment. In natural settings were $\mathrm{Mn}^{2+}{ }_{(\mathrm{aq})}$ is abundant, such as in lake and marine water columns and in sediments (Burdige, 1993), interactions between vernadite and $\mathrm{Mn}^{2+}{ }_{\text {(aq) }}$ may induce morphological and mineralogical changes that could impact its reactivity and the fate of trace elements sorbed at its surface. Two main structural transformations were identified during reaction of $\delta-\mathrm{MnO}_{2}$ (synthetic vernadite) with $\mathrm{Mn}^{2+}{ }_{(\mathrm{aq})}$. At a low $\mathrm{Mn}^{2+}$ to $\delta-\mathrm{MnO}_{2}$ ratio $(<3.27$ $\left.\mathrm{mmol} \mathrm{g}{ }^{-1}\right), \delta-\mathrm{MnO}_{2}$ crystal size increased with $\mathrm{Mn}^{2+}{ }_{(\mathrm{aq})}$. At a $\mathrm{Mn}^{2+}$ to $\delta-\mathrm{MnO}_{2}$ ratio of $3.27 \mathrm{mmol} \mathrm{g}^{-1}$ or higher, $\delta-\mathrm{MnO}_{2}$ was converted to synthetic feitknechtite, and the size of synthetic feitknechtite crystals was observed to increase with $\mathrm{Mn}^{2+}{ }_{(\mathrm{aq})}$. $\delta-\mathrm{MnO}_{2}$ with orthogonal layer symmetry was not detected as a transformation intermediate, possibly because experiments were conducted at slightly acidic $\mathrm{pH}$ (Zhao et al., 2016).

When crystal size increases, the specific surface area, and especially the contribution of particle edges to this surface, decreases. Vernadite edge sites being reactive (Simanova et al., 2015), the increase in vernadite crystal size when in contact with $\mathrm{Mn}^{2+}{ }_{(\mathrm{aq})}$, even at low concentrations, can be detrimental to its trace-metal scavenging ability. By analogy, the same is expected for feitknechtite at high $\mathrm{Mn}^{2+}$ to $\delta-\mathrm{MnO}_{2}$ ratio. The impact of the vernadite-to-feitknechtite transformation on the fate of trace elements remains unclear, however. The lack of any significant dissolution of $\delta-\mathrm{MnO}_{2}$ potentially minimizes the release of trace metal elements along the reaction pathway, but their possible incorporation in the newly formed feitknechtite structure remains undocumented. Unlike tunnel structures, feitknechtite has been observed seldom in natural settings, probably because of its limited chemical stability and high sensitivity to fluctuation in redox conditions, which lead to its back-conversion to vernadite (Bargar et al., 2005). Consequently, no data are currently available to evaluate the affinity of trace elements for feitknechtite in natural settings. Similar to tunnel structures (Liu et al., 2004; Kumagai et al., 2005; Cui et al., 2011; Atkins et al., 2014), additional insights into vernadite reactivity in suboxic systems and its impact on the fate of trace metals could probably be sought experimentally as feitknechtite is frequently observed in laboratory experiments mimicking natural conditions (Hem et al., 1982; Murray et al., 1985; Wang et al., 2015).

Acknowledgements: S.G. acknowledges funding by the French National Research Agency (ANR, grant ANR-14CE01-0006) and thanks Jacques Deparis, Nicolas Marty and Julie Philibert for fruitful discussions. SOLEIL data were acquired in the frame of proposal 20141260. A. Fernandez-Martinez and T. Conte are respectively thanked for help during XRD data collection and $\mathrm{Mn}^{2+}$ measurement. This article benefited from comments and suggestions by an anonymous reviewer and Alain Baronnet.

\section{References}

Appelo, C.A.J. \& Postma, D. (1999): A consistent model for surface complexation on birnessite $\left(\delta-\mathrm{MnO}_{2}\right)$ and its application to a column experiment. Geochim. Cosmochim. Acta, 63, 3039-3048.

Atkins, A.L., Shaw, S., Peacock, C.L. (2014): Nucleation and growth of todorokite from birnessite: implications for trace-metal cycling in marine sediments. Geochim. Cosmochim. Acta, 144, 109-125.

_, _, - (2016): Release of Ni from birnessite during transformation of birnessite to todorokite: implications for $\mathrm{Ni}$ cycling in marine sediments. Geochim. Cosmochim. Acta, 189, 158-183.

Bargar, J.R., Tebo, B.M., Bergmann, U., Webb, S.M., Glatzel, P., Chiu, V.Q., Villalobos, M. (2005): Biotic and abiotic products of $\mathrm{Mn}(\mathrm{II})$ oxidation by spores of the marine Bacillus sp. strain SG-1. Am. Mineral., 90, 143-154.

Bargar, J.R., Fuller, C.C., Marcus, M.A., Brearley, A.J., Perez De la Rosa, M., Webb, S.M., Caldwell, W.A. (2009): Structural characterization of terrestrial microbial Mn oxides from Pinal Creek, AZ. Geochim. Cosmochim. Acta, 73, 889-910.

Barrett, K.A. \& McBride, M.B. (2005): Oxidative degradation of glyphosate and aminomethylphosphonate by manganese oxide. Environ. Sci. Technol., 39, 9223-9228.

Bellanca, A., Hauser, S., Neri, R., Palumbo, B. (1996): Mineralogy and geochemistry of Terra Rossa soils, western Sicily: insights into heavy metal fractionation and mobility. Sci. Total Environ., 193, 57-67.

Birnie, A.C. \& Paterson, E. (1991): The mineralogy and morphology of iron and manganese oxides in an imperfectlydrained Scottish soil. Geoderma, 50, 219-237.

Bodeï, S., Manceau, A., Geoffroy, N., Baronnet, A., Buatier, M. (2007): Formation of todorokite from vernadite in Ni-rich hemipelagic sediments. Geochim. Cosmochim. Acta, 71, 5698-5716.

Boonfueng, T., Axe, L., Xu, Y., Tyson, T.A. (2006): The impact of $\mathrm{Mn}$ oxide coatings on $\mathrm{Zn}$ distribution. J. Colloid Interface Sci., 298, 615-623.

Bricker, O. (1965): Some stability relations in the system $\mathrm{Mn}-\mathrm{O}_{2}-$ $\mathrm{H}_{2} \mathrm{O}$ at $25^{\circ}$ and one atmosphere total pressure. Am. Mineral., 50, 1296-1354.

Burdige, D.J. (1993): The biogeochemistry of manganese and iron reduction in marine sediments. Earth-Sci. Rev., 35, 249-284.

Chang Chien, S.W., Chen, H.L., Wang, M.C., Seshaiah, K. (2009): Oxidative degradation and associated mineralization of catechol, hydroquinone and resorcinol catalyzed by birnessite. Chemosphere, 74, 1125-1133.

Chen, C.C., Golden, D.C., Dixon, J.B. (1986): Transformation of synthetic birnessite to cryptomelane - an electron-microscopic study. Clays Clay Miner., 34, 565-571.

Cheney, M.A., Sposito, G., McGrath, A.E., Criddle, R.S. (1996): Abiotic degradation of 2,4-D (dichlorophenoxyacetic acid) on synthetic birnessite: a calorespirometric method. Colloid Surf. A, 107, 131-140.

Chukhrov, F.V., Sakharov, B.A., Gorshkov, A.I., Drits, V.A., Dikov, Y.P. (1985): Crystal structure of birnessite from the Pacific ocean. Int. Geol. Rev., 27, 1082-1088.

Cui, H.-J., Liu, F., Tan, W.-F., Feng, X.-H. (2011): Effect of cobaltdoped framework on formation of todorokite from layered manganese oxides with $\mathrm{Mg}^{2+} / \mathrm{Co}^{2+}$ ions as template. Pedosphere, 21, 730-737.

Cygan, R.T., Post, J.E., Heaney, P.J., Kubicki, J.D. (2012): Molecular models of birnessite and related hydrated layered minerals. Am. Mineral., 97, 1505-1514. 
Drits, V.A., Lanson, B., Gaillot, A.-C. (2007): Birnessite polytype systematics and identification by powder X-ray diffraction. Am. Mineral., 92, 771-788.

Duff, M.C., Hunter, D.B., Triay, I.R., Bertsch, P.M., Reed, D.T., Sutton, S.R., Shea-McCarthy, G., Kitten, J., Eng, P., Chipera, S.J., Vaniman, D.T. (1999): Mineral associations and average oxidation states of sorbed Pu on tuff. Environ. Sci. Technol., 33, 2163-2169.

Elzinga, E.J. (2011): Reductive transformation of birnessite by aqueous Mn(II). Environ. Sci. Technol., 45, 6366-6372.

- (2016): ${ }^{54} \mathrm{Mn}$ radiotracers demonstrate continuous dissolution and reprecipitation of vernadite $\left(\delta-\mathrm{MnO}_{2}\right)$ during interaction with aqueous Mn(II). Environ. Sci. Technol., 50, 8670-8677.

Elzinga, E.J. \& Kustka, A.B. (2015): A Mn-54 radiotracer study of $\mathrm{Mn}$ isotope solid-liquid exchange during reductive transformation of vernadite $\left(\delta-\mathrm{MnO}_{2}\right)$ by aqueous $\mathrm{Mn}(\mathrm{II})$. Environ. Sci. Technol., 49, 4310-4316.

Fendorf, S.E., Sparks, D.L., Franz, J.A., Camaioni, D.M. (1993): Electron paramagnetic resonance stopped-flow kinetic study of manganese(II) sorption-desorption on birnessite. Soil Sci. Soc. Am. J., 57, 57-62.

Fuller, C.C. \& Bargar, J.R. (2014): Processes of zinc attenuation by biogenic manganese oxides forming in the hyporheic zone of Pinal Creek, Arizona. Environ. Sci. Technol., 48, 2165-2172.

Giovanoli, R. (1980): Vernadite is random-stacked birnessite. Miner. Depos., 15, 251-253.

Giovanoli, R., Stähli, E., Feitknecht, W. (1970): Über Oxidhydroxide des vierwertigen Mangans mit Schichtengitter. 1. Mitteilung: Natriummangan (II, III) manganat (IV). Helv. Chim. Acta, 59, 209-220.

Grangeon, S., Lanson, B., Lanson, M., Manceau, A. (2008): Crystal structure of Ni-sorbed synthetic vernadite: a powder X-ray diffraction study. Mineral. Mag., 72, 1197-1209.

Grangeon, S., Lanson, B., Miyata, N., Tani, Y., Manceau, A. (2010): Structure of nanocrystalline phyllomanganates produced by freshwater fungi. Am. Mineral., 95, 1608-1616.

Grangeon, S., Manceau, A., Guilhermet, J., Gaillot, A.-C., Lanson, M., Lanson, B. (2012): Zn sorption modifies dynamically the layer and interlayer structure of vernadite. Geochim. Cosmochim. Acta, 85, 302-313.

Grangeon, S., Lanson, B., Lanson, M. (2014): Solid-state transformation of nanocrystalline phyllomanganate into tectomanganate: influence of initial layer and interlayer structure. Acta Crystallogr. B, 70, 828-838.

Grangeon, S., Fernandez-Martinez, A., Warmont, F., Gloter, A., Marty, N., Poulain, A., Lanson, B. (2015): Cryptomelane formation from nanocrystalline vernadite precursor: a high energy X-ray scattering and transmission electron microscopy perspective on reaction mechanisms. Geochem. Trans., 16, 12.

Grangeon, S., Fernandez-Martinez, A., Claret, F., Marty, N., Tournassat, C., Warmont, F., Gloter, A. (2017): In-situ determination of the kinetics and mechanisms of nickel adsorption by nanocrystalline vernadite. Chem. Geol., 459, 24-31.

Halbach, P. (1986): Processes controlling the heavy metal distribution in Pacific ferromanganese nodules and crusts. Int. J. Earth Sci., 75, 235-247.

Hem, J.D., Roberson, C.E., Fournier, R.B. (1982): Stability of $\beta \mathrm{MnOOH}$ and manganese oxide deposition from springwater. Water Resour. Res., 18, 563-570.
Hochella Jr., M.F., Kasama, T., Putnis, A., Putnis, C.V., Moore, J.N. (2005): Environmentally important, poorly crystalline Fe/Mn hydrous oxides: ferrihydrite and a possibly new vernadite-like mineral from the Clark Fork River Superfund Complex. Am. Mineral., 90, 718-724.

Hockridge, J.G., Jones, F., Loan, M., Richmond, W.R. (2009): An electron microscopy study of the crystal growth of schwertmannite needles through oriented aggregation of goethite nanocrystals. J. Cryst. Growth, 311, 3876-3882.

Jia, B. \& Gao, L. (2008a): Growth of well-defined cubic hematite single crystals: oriented aggregation and ostwald ripening. Cryst. Growth Des., 8, 1372-1376.

- - - (2008b): Morphological transformation of $\mathrm{Fe}_{3} \mathrm{O}_{4}$ spherical aggregates from solid to hollow and their self-assembly under an external magnetic field. J. Phys. Chem. C, 112, 666-671.

Johnson, K., Purvis, G., Lopez-Capel, E., Peacock, C., Gray, N., Wagner, T., März, C., Bowen, L., Ojeda, J., Finlay, N., Robertson, S., Worrall, F., Greenwell, C. (2015): Towards a mechanistic understanding of carbon stabilization in manganese oxides. Nat. Commun., 6, 7628.

Johnson, J.E., Savalia, P., Davis, R., Kocar, B.D., Webb, S.M., Nealson, K.H., Fischer, W.W. (2016): Real-time manganese phase dynamics during biological and abiotic manganese oxide reduction. Environ. Sci. Technol., 50, 4248-4258.

Jurgensen, A., Widmeyer, J.R., Gordon, R.A., Bendell-Young, L.I., Moore, M.M., Crozier, E.D. (2004): The structure of the manganese oxide on the sheath of the bacterium Leptothrix discophora: an XAFS study. Am. Mineral., 89, 1110-1118.

Koppi, A.J., Edis, R., Field, D.J., Geering, H.R., Klessa, D.A., Cockayne, D.J.H. (1996): Rare earth element trends and cerium-uranium-manganese associations in weathered rock from Koongarra, Northern Territory, Australia. Geochim. Cosmochim. Acta, 60, 1695-1707.

Kumagai, N., Komaba, S., Abe, K., Yashiro, H. (2005): Synthesis of metal-doped todorokite-type $\mathrm{MnO}_{2}$ and its cathode characteristics for rechargeable lithium batteries. J. Power Sources, SI 146, 310-314.

Kunzendorf, H. \& Friedrich, G.H.W. (1976): The distribution of U and Th in growth zones of manganese nodules. Geochim. Cosmochim. Acta, 40, 849-852.

Lanson, B., Drits, V.A., Silvester, E., Manceau, A. (2000): Structure of $\mathrm{H}$-exchange hexagonal birnessite and its mechanism of formation from Na-rich monoclinic buserite at low pH. Am. Mineral., 85, 826-838.

Lanson, B., Marcus, M.A., Fakra, S., Panfili, F., Geoffroy, N., Manceau, A. (2008): Formation of $\mathrm{Zn}-\mathrm{Ca}$ phyllomanganate nanoparticles in grass roots. Geochim. Cosmochim. Acta, 72, 2478-2490.

Lefkowitz, J.P. \& Elzinga, E.J. (2015): Impacts of aqueous Mn(II) on the sorption of $\mathrm{Zn}(\mathrm{II})$ by hexagonal birnessite. Environ. Sci. Technol., 49, 4886-4893.

Lefkowitz, J.P., Rouff, A.A., Elzinga, E.J. (2013): Influence of pH on the reductive transformation of birnessite by aqueous $\mathrm{Mn}(\mathrm{II})$. Environ. Sci. Technol., 47, 10364-10371.

Liu, J., Son, Y.C., Cai, J., Shen, X.F., Suib, S.L., Aindow, M. (2004): Size control, metal substitution, and catalytic application of cryptomelane nanomaterials prepared using cross-linking reagents. Chem. Mater, 16, 276-285. 
Manceau, A., Drits, V.A., Silvester, E., Bartoli, C., Lanson, B (1997): Structural mechanism of $\mathrm{Co}^{2+}$ oxidation by the phyllomanganate buserite. Am. Mineral., 82, 1150-1175.

Manceau, A., Marcus, M.A., Tamura, N., Proux, O., Geoffroy, N., Lanson, B. (2004): Natural speciation of $\mathrm{Zn}$ at the micrometer scale in a clayey soil using X-ray fluorescence, absorption, and diffraction. Geochim. Cosmochim. Acta, 68, 2467-2483.

Manceau, A., Kersten, M., Marcus, M.A., Geoffroy, N., Granina, L. (2007): Ba and Ni speciation in a nodule of binary Mn oxide phase composition from Lake Baikal. Geochim. Cosmochim. Acta, 71, 1967-1981.

Manceau, A., Marcus, M.A., Grangeon, S., Lanson, M., Lanson, B., Gaillot, A.C., Skanthakumar, S., Soderholm, L. (2013): Shortrange and long-range order of phyllomanganate nanoparticles determined using high-energy X-ray scattering. J. Appl. Crystallogr., 46, 193-209.

Manceau, A., Lanson, M., Takahashi, Y. (2014): Mineralogy and crystal chemistry of $\mathrm{Mn}, \mathrm{Fe}, \mathrm{Co}, \mathrm{Ni}$, and $\mathrm{Cu}$ in a deep-sea Pacific polymetallic nodule. Am. Mineral., 99, 2068-2083.

Marcus, M.A., Manceau, A., Kersten, M. (2004): Mn, Fe, Zn and As speciation in a fast-growing ferromanganese marine nodule. Geochim. Cosmochim. Acta, 68, 3125-3136.

Murray, J.W. (1975): The interaction of metal ions at the manganese dioxide-solution interface. Geochim. Cosmochim. Acta, 39 , 505-519.

Murray, J.W., Dillard, J.G., Giovanoli, R., Moers, H., Stumm, W. (1985): Oxidation of $\mathrm{Mn}(\mathrm{II})$ : initial mineralogy, oxidation state and ageing. Geochim. Cosmochim. Acta, 49, 463-470.

Nasser, A., Sposito, G., Cheney, M.A. (2000): Mechanochemical degradation of 2,4-adsorbed on synthetic birnessite. Colloid Surf. A, 163, 117-123.

Niederberger, M. \& Colfen, H. (2006): Oriented attachment and mesocrystals: non-classical crystallization mechanisms based on nanoparticle assembly. Phys. Chem. Chem. Phys., 8, 3271-3287.

Ounsy, M., Girardot, R., Saintin, K., Viguier, G. (2013): Online data reduction for high throughput beamlines. in "International Conference on Accelerators and Large Experimental Physics Control Systems, San Francisco, USA, 7-11 October 2013".

Peacock, C.L. \& Sherman, D.M. (2007): Crystal-chemistry of Ni in marine ferromanganese crusts and nodules. Am. Mineral., 92, 1087-1092.

Peña, J., Kwon, K.D., Refson, K., Bargar, J.R., Sposito, G. (2010): Mechanisms of nickel sorption by a bacteriogenic birnessite. Geochim. Cosmochim. Acta, 74, 3076-3089.

Penn, R.L. (2004): Kinetics of oriented aggregation. J. Phys. Chem. $B, \mathbf{1 0 8}, 12707-12712$.

Portehault, D., Cassaignon, S., Baudrin, E., Jolivet, J.-P. (2007): Morphology control of cryptomelane type $\mathrm{MnO}_{2}$ nanowires by soft chemistry. Growth mechanisms in aqueous medium. Chem. Mater., 19, 5410-5417.

Ross, S.J., Franzmeier, D.P., Roth, C.B. (1976): Mineralogy and chemistry of manganese oxides in some Indiana soils. Soil Sci. Soc. Am. J., 40, 137-143.

Schneider, C.A., Rasband, W.S., Eliceiri, K.W. (2012): NIH Image to ImageJ: 25 years of image analysis. Nat. Methods, 9, 671-675.

Shen, Q., Wang, L., Huang, Y., Sun, J., Wang, H., Zhou, Y., Wang, D. (2006): Oriented aggregation and novel phase transformation of vaterite controlled by the synergistic effect of calcium dodecyl sulfate and n-pentanol. J. Phys. Chem. B, 110, 23148-23153.
Simanova, A.A., Kwon, K.D., Bone, S.E., Bargar, J.R., Refson, K., Sposito, G., Peña, J. (2015): Probing the sorption reactivity of the edge surfaces in birnessite nanoparticles using nickel(II). Geochim. Cosmochim. Acta, 164, 191-204.

Taylor, R.M. (1968): The association of manganese and cobalt in soils - further observations. J. Soil Sci., 19, 77-80.

Taylor, R., McKenzie, R., Norrish, K. (1964): The mineralogy and chemistry of manganese in some Australian soils. Aust. J. Soil Res., 2, 235-248.

Tonkin, J.W., Balistrieri, L.S., Murray, J.W. (2004): Modeling sorption of divalent metal cations on hydrous manganese oxide using the diffuse double layer model. Appl. Geochem., 19, 29-53.

Tournassat, C., Grangeon, S., Leroy, P., Giffaut, E. (2013): Modeling specific $\mathrm{pH}$ dependent sorption of divalent metals on montmorillonite surfaces. A review of pitfalls, recent achievements and current challenges. Am. J. Sci., 313, 395-451.

Tu, S.H., Racz, G.J., Goh, T.B. (1994): Transformations of synthetic birnessite as affected by $\mathrm{pH}$ and manganese concentration. Clays Clay Miner., 42, 321-330.

Villalobos, M., Toner, B., Bargar, J., Sposito, G. (2003): Characterization of the manganese oxide produced by Pseudomonas putida strain MnB1. Geochim. Cosmochim. Acta, 67, 2649-2662.

Villalobos, M., Lanson, B., Manceau, A., Toner, B., Sposito, G. (2006): Structural model for the biogenic Mn oxide produced by Pseudomonas putida. Am. Mineral., 91, 489-502.

Wang, X., Lan, S., Zhu, M., Ginder-Vogel, M., Yin, H., Liu, F., Tan, W., Feng, X. (2015): The presence of ferrihydrite promotes abiotic formation of manganese (oxyhydr)oxides. Soil Sci. Soc. Am. J., 79, 1297-1305.

Webb, S.M., Tebo, B.M., Bargar, J.R. (2005): Structural characterization of biogenic $\mathrm{Mn}$ oxides produced in seawater by the marine Bacillus sp. strain SG-1. Am. Mineral., 90, 1342-1357.

Wegorzewski, A.V., Kuhn, T., Dohrmann, R., Wirth, R., Grangeon, S. (2015): Mineralogical characterization of individual growth structures of Mn-nodules with different Ni plus $\mathrm{Cu}$ content from the central Pacific Ocean. Am. Mineral., 100, 2497-2508.

Xin, X., Jiang, X., Su, J., Yan, X., Ni, J., Faeflen, S.J., Huang, X., Wright, A.L. (2016): Manganese oxide affects nitrification and ammonia oxidizers in subtropical and temperate acid forest soils. Catena, 137, 24-30.

Xu, H., Chen, T., Konishi, H. (2010): HRTEM investigation of trilling todorokite and nano-phase Mn-oxides in manganese dendrites. Am. Mineral., 95, 556-562.

Yuwono, V.M., Burrows, N.D., Soltis, J.A., Penn, R.L. (2010): Oriented aggregation: formation and transformation of mesocrystal intermediates revealed. J. Am. Chem. Soc., 132, 2163-2165.

Zhao, H., Zhu, M., Li, W., Elzinga, E.J., Villalobos, M., Liu, F., Zhang, J., Feng, X., Sparks, D.L. (2016): Redox reactions between $\mathrm{Mn}(\mathrm{II})$ and hexagonal birnessite change its layer symmetry. Environ. Sci. Technol., 50, 1750-1758.

Zhu, M., Ginder-Vogel, M., Parikh, S.J., Feng, X.-H., Sparks, D.L. (2010): Cation effects on the layer structure of biogenic Mnoxides. Environ. Sci. Technol., 44, 4465-4471.

Received 23 December 2016

Modified version received 20 March 2017

Accepted 21 May 2017 